\title{
Cultural Therapeutic Awareness and Sickle Cell Anemia
}

\author{
Karen D. Scott \\ Our Lady of the Lake University, \\ San Antonio, Texas \\ Anthony A. Scott \\ University of Texas Health Science Center, \\ San Antonio
}

\begin{abstract}
Sickle cell anemia is a hereditary blood disorder in which abnormal red blood cells damage the cerebrovascular system as well as organs such as the liver and spleen. Children with sickle cell anemia manifest high mortality rates, depression, pain, strokes, and social maladjustment. Interventions often challenge the family's beliefs and attitudes. A cognitive behavioral approach, the Health Belief Model, was offered as a strategic option in working with African American clients diagnosed with sickle cell anemia. Two descriptive case studies were presented. Whereas one case illustrated a lack of a coordinated system of care, the other demonstrated the effectiveness of a multidisciplinary system of services. The purpose of this article is to present a brief description of the medical, neurological, and psychoeducational problems caused by sickle cell anemia and to suggest that services be provided by culturally competent, systems-oriented professionals.
\end{abstract}

Sickle cell anemia is an inherited blood disorder that occurs primarily in African American populations (Carter, 1983; Nash, 1994; Powars, Overturf, \& Weiss, 1981). One in every 12 African Americans passes the sickle cell trait on to his or her children, with a $10 \%$ mortality rate for children within the first 5 years of their lives (Chapar, Blair, \& Stowe, 1991; Powars et al., 1981;

AUTHORS' NOTE: Correspondence and reprint requests should be sent to Anthony A. Scott, Department of Pediatrics, University of Texas Health Science Center at San Antonio, 7703 Floyd Curl Drive, San Antonio, TX 78284-7792; phone: (210) 567-7400; fax: (210) 567-7443; e-mail: scottaa@uthscsa.edu.

JOURNAL OF BLACK PSYCHOLOGY, Vol. 25 No. 3, August 1999 316-335

() 1999 The Association of Black Psychologists 
Segal, 1989; Whitten, 1992). This rates sickle cell anemia among the most prevalent genetic diseases in the United States (Behram \& Vaughan, 1983).

Sickle cell anemia is a type of chronic anemia (Carter, 1983), whereas sickle cell trait occurs as a mutation of the hemoglobin (Francis \& Johnson, 1991). An inheritance of the sickled genes causes red blood cell abnormality (Drotar, Baskiewicz, Irvin, Kennell, \& Klaus, 1975). When both parents have the sickle trait, there is a one in four chance that the baby will have normal hemoglobin, a two in four chance that the baby will have the sickle trait, and a one in four chance that the baby will have sickle cell anemia (Wang, Grover, \& Gallagher, 1993). The two parental blood types inherited will determine the shape of the red blood cells (Whitten, 1992).

All complications of sickle cell anemia can be traced to changes in the makeup of red blood cells (Wang et al., 1993). Sickled red blood cells can become trapped within the blood vessels and thereby interfere with normal blood flow (Sergeant, 1992). Under certain conditions such as dehydration, infection, and low oxygen, red blood cells become rigid, elongated, and sickle-shaped (Sergeant, 1992).

As with any anemia, a decrease of oxygen causes fatigue. Obstruction of oxygen flow within the red blood cells (hypoxia) causes the sickling effect to develop and increase, the death of cells and tissues (necrosis), clotting (thrombosis), hemorrhaging, obstruction of blood vessels (occlusion), circulation difficulties, fatigue, extensive damage to multiple organ systems, and chronic pain (Carter, 1983; Whitten, 1992). In addition, detrimental effects on the central nervous system such as cerebrovascular accidents (strokes) are evident (Sergeant, 1992). Chronic arthritis and respiratory infections as well as damage to the spleen, eyes, and other organ systems also occur (Mills, 1985).

Children with sickle cell anemia are particularly vulnerable to neurophysiological manifestations such as strokes, seizures, and infections as well as cognitive and psychological problems (Armstrong et al., 1996; Whitten, 1992). In addition, this illness is complicated by a lack of adequate insurance and a lack of information available to families, educators, health professionals, and patients about the extent of the illness and the available approaches to treatment (Farber, Koshy, \& Kinney, 1985). Also, for the majority of sufferers, the illness is complicated by low socioeconomic status (SES) and inadequate health insurance coverage (Whitten, 1992).

Children with sickle cell anemia in upper SES families scored higher on intelligence tests (Brown, Kaslow, \& Doepke, 1993). Lower SES has been correlated with maladaptive coping and adjustment for both children with sickle cell anemia and their parents (Brown, Kaslow, et al., 1993; Swift, Cohen, \& Hynd, 1989). Unlike other chronic congenital illnesses, sickle cell 
anemia receives minimal federal, state, and local funding, which further inhibits patients from receiving appropriate health care (Brown, Kaslow, et al., 1993). Appropriate health care would include providing care for the relief of physical pain as well as services for the patient's psychological, neurological, social, and educational needs (Carter, 1983; Whitten, 1992). Furthermore, the overall functioning of individuals with sickle cell anemia can be improved by the use of a comprehensive program that includes medical treatment, psychosocial services, and family-centered, culturally sensitive systemic therapeutic interventions (Sickle Cell Disease Guideline Panel, 1990, 1993; Telfair, 1994; Whitten, 1992; Woods, Yates, \& Primomo, 1989).

The Health Belief Model (HBM) is a psychosocial intervention model that considers the client's health knowledge as well as his or her beliefs, attitudes, behaviors, and surrounding systems. In addition, the HBM allows for the implementation of a comprehensive approach to the management of sickle cell anemia that includes newborn screening and follow-up, disease education, genetic counseling, counseling for the family, developmental and academic intervention, family case management, coordinated medical care with an emphasis on continuity of care, and community involvement (Figure 1). Community involvement includes churches, extended family members, neighbors, and schools.

\section{REVIEW OF THE LITERATURE}

\section{PHYSICAL LIMITATIONS OF SICKLE CELL ANEMIA}

Varying physical limitations from sickle cell anemia are noted at each developmental stage. The initial manifestation of the illness in infancy may be pain and swelling in the hands and feet (dactylitis) (Berg, 1994). Dactylitis has been reported to occur between the ages of 3 months and 1 year (Behram \& Vaughan, 1983). Sequestration crisis, where large amounts of blood collect in the liver and spleen, is one of the most frequent causes of death in infants with sickle cell anemia (Avery \& First, 1989). The resulting liver and spleen dysfunctions contribute to visible jaundice and a variety of infectious conditions such as sepsis. Sepsis is the main cause of death in children with sickle cell anemia within the first 3 to 5 years of life (Berg, 1994).

Segal (1989) claimed that early identification and treatment (i.e., penicillin therapy) beginning at 3 months of age and vaccination against pneumococcal infections at 2 years of age would virtually eliminate death from infection in children up to 4 years of age. Children under 5 years of age are more 


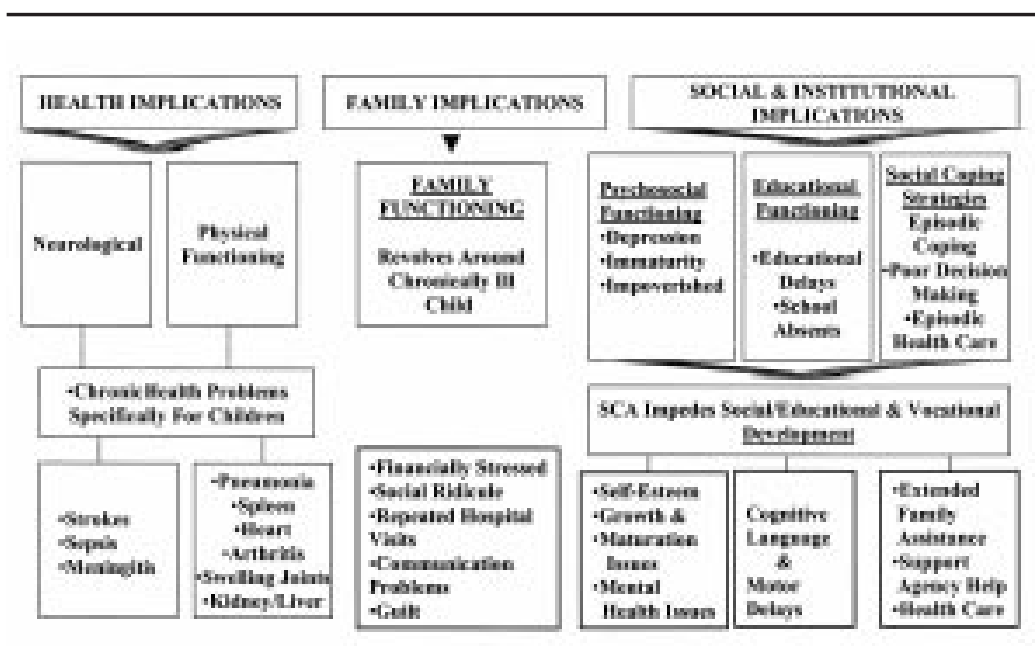

Figure 1: Description of Sickle Cell Anemia

NOTE: SCA = sickle cell anemia.

prone to infections, infarctions, and dactylitis, whereas children over 5 and adolescents are challenged by leg ulcers, bone necrosis, and delayed growth (Brown, Armstrong, \& Eckmen, 1993; Sergeant, 1974).

In addition, children with sickle cell anemia often experience delays in achieving developmental milestones (Whitten, 1992). For example, whereas younger children with sickle cell anemia might experience delays in walking and talking, adolescents with sickle cell anemia often face delayed puberty. This delay in growth often negatively affects the interpersonal relationships of the adolescent, which leads to low self-esteem and depression (Brown, Kaslow, et al., 1993). Sickle cell anemia also is associated with lifelong emotional, behavioral, and physical dysfunctions (Fowler, Whitt, \& Lallinger, 1988). Physical limitations, such as having frail bone structures, also affect the child's ability to participate in physical activities. The child's decrease in physical activity often persists into adulthood. As an adult, the individual is able to achieve only approximately $50 \%$ of the physical exertion needed to complete a task (Department of Health and Human Services, 1992).

Sickle cell anemia also causes transient neurological symptoms that may cause visual disturbances, disorientation, and loss of consciousness (Brown, Kaslow, et al., 1993). However, the most common physical symptom is recurrent pain (Berg, 1994). Individuals with sickle cell anemia have a lifetime propensity for pain attacks that vary with respect to frequency, duration, and 
severity (Whitten, 1992). The severity of pain attacks can vary from pain that can be managed at home without medication to pain that will not subside without the addition of narcotics and hospitalization. Pain management, therefore, lies at the core of treatment. Unfortunately, many physicians are reluctant to continue the prescription of pain medications for fear of fostering an addiction to the drugs (Berg, 1994).

\section{NEUROLOGICAL AND NEUROPSYCHOLOGICAL IMPLICATIONS}

Neuropsychological deficits often are misdiagnosed (Charache, Lubin, \& Reid, 1989). Clinical strokes affect $5 \%$ to $10 \%$ of children with sickle cell anemia, and silent strokes affect approximately $16 \%$ to $20 \%$ of those under 15 years of age (Brown, Armstrong, et al., 1993). Strokes can result in intellectual, motor, and sensory impairment with outcomes ranging from complete recovery to death (Brown, Armstrong, et al., 1993; Department of Health and Human Services, 1992). The severity of the deficit is influenced by the amount of bleeding or clotting, the localization of the lesion, the size of the infarct, and the age of the patient (Sergeant, 1992).

The neurocognitive effects of sickle cell anemia are multifaceted (Fowler et al., 1988). Currently, Brown, Kaslow, et al. (1993) found older children to have greater impairments in sustained attention and academic achievement measures than younger children. Impairments in visual motor skills, attention, and reading recognition also were noted among children age 13 years or over (Behram \& Vaughan, 1983; Fowler et al., 1988).

Wasserman, Wilimas, Fairclough, Mulhern, and Wang (1991) became interested in whether sickle cell anemia affected a child's general global intelligence. They found that the full-scale, verbal, and performance IQ score means of children with sickle cell anemia between 8 and 16 years of age were lower than those of a control group. However, only the performance IQ and full-scale IQ differences were significant. In fact, both children with sickle cell anemia and children in the control group were within the average range of general intelligence.

Although children with sickle cell anemia fall within the average range of intelligence, specific deficits are noted in areas such as attention, concentration, and distractibility (Brown, Buchanan, et al., 1993; Fowler et al., 1988; Swift et al., 1989). In addition, children with sickle cell anemia have significantly impaired visual-spatial abilities. This is cited in the literature as visual perceptual, visual motor, perceptual organization, and nonverbal cognition (Behram \& Vaughan, 1983; Swift et al., 1989; Wang et al., 1993). However, 
deficits in memory, processing skills, and verbal skills have been replicated less consistently (Brown, Buchanan, et al., 1993).

\section{PSYCHOEDUCATIONAL IMPLICATIONS}

Academic differences between children with sickle cell anemia and a control group are due to subtle neurological and learning deficits (Brown, Armstrong, et al., 1993; Fowler et al., 1988). Significant deficits in academic achievement, including reading and spelling difficulties, have been noted (Brown, Kaslow, et al., 1993). Although it is more acceptable to think that medically related absenteeism is the culprit, the academic difficulties of children with sickle cell anemia are related to more than this simple factor (Nash, 1994). For example, Eaton, Hayes, and Armstrong (1991) found that the amount of school absenteeism was not associated with grades or standardized test performance. Brown, Buchanan, et al. (1993) contended that observed academic difficulties in children with sickle cell anemia are related primarily to specific health problems and socioeconomic factors. Furthermore, Fowler and colleagues (1988) found that children afflicted with sickle cell anemia, when compared to nonafflicted matched peers, demonstrated significantly lower achievement scores in areas such as reading and spelling. They suggested that the noted differences are related to subtle neurological and learning deficits.

\section{PSYCHOSOCIAL IMPLICATIONS}

The health status of individuals with sickle cell anemia has a tremendous impact on psychosocial functioning because the illness often serves to isolate the patient and affects self-image development (Wasserman et al., 1991). Individuals with sickle cell anemia are isolated by many factors related to the disease process itself (Charache et al., 1989). Figure 2 addresses some of the risk factors that threaten the health management system and homeostatic balance of the family. Inactivity or irregular involvement in activity can produce emotional stress and interfere with the mastery of social skills. The limited school and social activities in which the individual participates frequently are interrupted by unpredictable pain attacks and repeated hospitalizations (Telfair, 1994).

Although older children with sickle cell anemia often report feeling less accepted by peers and less competent than controls, younger children with sickle cell anemia tend to have social competencies similar to their 


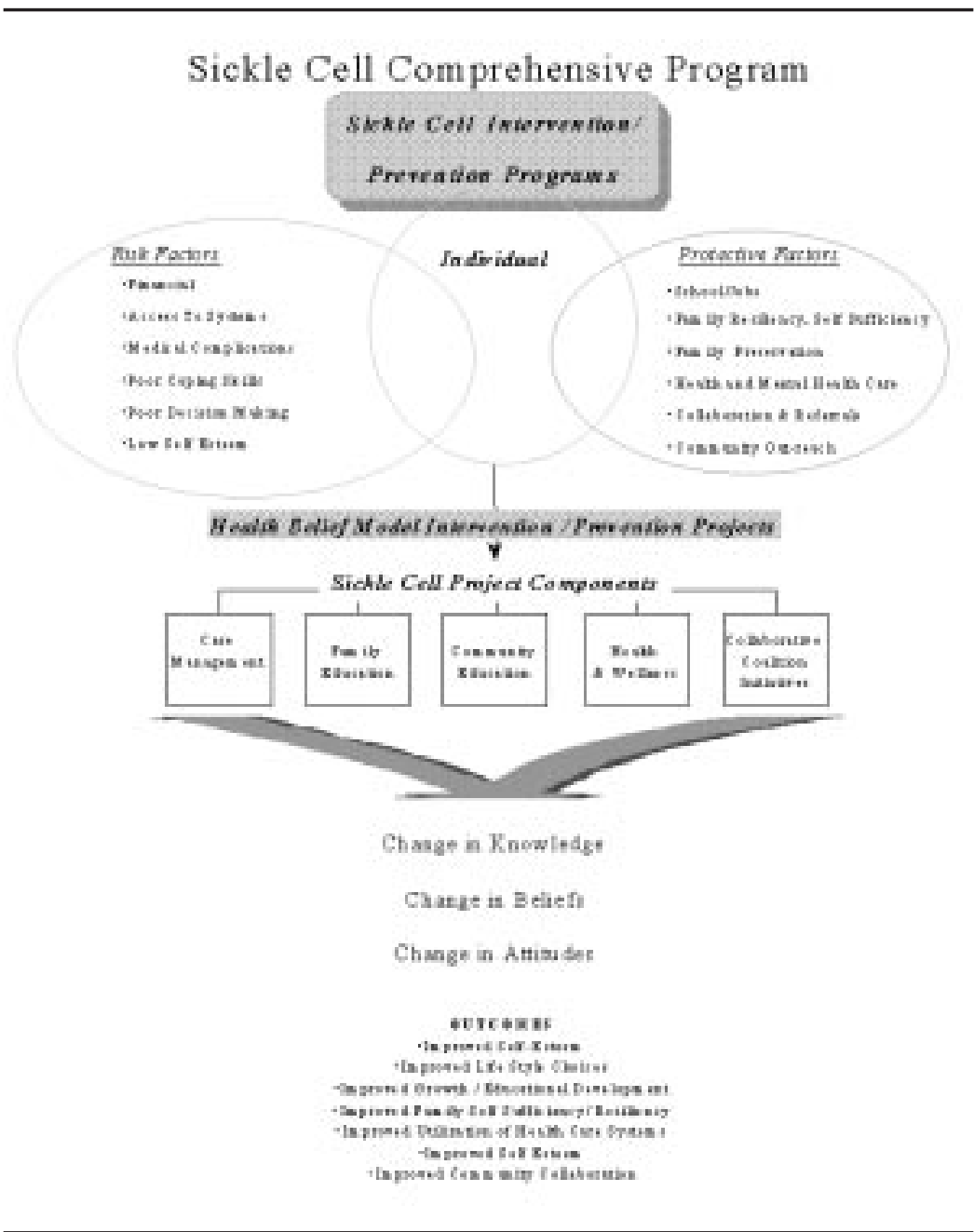

Figure 2: System of Care for Sickle Cell Clients

counterparts (Brown, Armstrong, et al., 1993; Brown, Kaslow, et al., 1993; Lemanek, Horwitz, \& Ohene-Frempong, 1994). Adolescents experience more difficulty with personality adjustment and school performance in comparison to younger children with sickle cell anemia (Hurtig, Koepke, \& Park, 1989). 
Identity issues, which are important to all adolescents, are exacerbated by the chronic illness. Male adolescents with sickle cell anemia tend to display a disruption of normative behavior compared to adolescent controls (Nash, 1994). However, regardless of gender, adolescents with sickle cell anemia spend less time in activities and are less satisfied with their bodies in comparison to their peers (Brown, Armstrong, et al., 1993). Difficulties with adjustment, acting out, and immaturity clearly are related to the disease process (Charache et al., 1989).

As children with sickle cell anemia age, their adaptive skills become less effective and they experience decreased social support (Brown, Kaslow, et al., 1993). Because high self-esteem, knowledge regarding illness, and family cohesion are associated with lower levels of depression and anxiety, social support is essential in illness adjustment (Nash, 1994; Telfair, 1994). In fact, Barbarin, Whitten, and Bonds (1994) found that 25\% of an urban sample of children with sickle cell anemia displayed symptoms of anxiety and depression. Possible contributing factors to depression and sickle cell anemia include unpredictable chronic pain, lack of a cure, and decreased life expectancy (Segal, 1989). The uncertainty of the illness might increase the risk of depression due to the patient's lack of control over his or her life (Brown, Armstrong, et al., 1993).

Among adults with sickle cell anemia, the struggles with loneliness, low self-esteem, and relational difficulties are common (Brown, Armstrong, et al., 1993). In addition, depression significantly affects individuals with sickle cell anemia, and depressive scores frequently approach the pathological range (Brown, Kaslow, et al., 1993). Work functioning often is affected by recurrent pain episodes, which leads to high rates of unemployment (Department of Health and Human Services, 1992).

\section{COPING STRATEGIES AND RESILIENCY}

The coping strategies of a family experiencing a chronic illness are among the most important variables affecting the resiliency of the client and family as a unit (Austin, 1990). Other key resiliency variables are social competence (e.g., flexibility, good communication skills), effective problem-solving skills, self-sufficiency (e.g., internal locus of control, high self-esteem, selfdiscipline), and being achievement oriented (e.g., goal directed, optimistic, education oriented) (Cohen, Richardson, \& La Bree, 1994; Kazak, 1989; Knafl \& Deatrick, 1986, 1990; Pizzo, 1990; Rawlins, Rawlins, \& Horner, 1990; Schlomann, 1988; Urwin, 1988). 
Because parents often experience four stages of grief-disbelief, anger, demystification, and conditional acceptance-it is important to help identify the specific coping strategies needed to effectively accomplish grief work (Travis, 1976). Retrospective researchers emphasize the extreme distress of parents at the time sickle cell disease is diagnosed (Woods et al., 1989). Under normal conditions, the interactions between parents and infants are biologically biased in ways that guarantee routine bonding and positive parent-child relationships (Goldberg, 1977). However, the families rearing children with sickle cell disease frequently spend many hours with health management issues. Whereas Knafl and Deatrick (1986) analyzed the concept of normalization as it relates to how families respond to the chronic illness of family members, Schlomann (1988) reported the need to explore family strategies by providing a holistic approach to coping with the chronic illness.

Parents of children with a wide variety of chronic health issues were surveyed (Walker, Epstein, Taylor, Crocker, \& Tuttle, 1989). The majority of those surveyed revealed that many of the needs expressed by all parents regardless of insurance coverage, income, education, and the children's diagnoses are the ones usually not addressed by larger health service delivery systems such as counseling and family support groups (Kazak, 1989). Policy analysts (Dryfoos, 1990) listed some common social support factors that influence program effectiveness and program outcomes. Specifically, these factors include availability of well-trained and highly skilled staff to facilitate learning and training skills, early interventions that emphasize family involvement, culturally sensitive individual interventions, and follow-up services. This would involve a full range of comprehensive services under one roof including physical, mental, and psychological services; schoolimplemented vocational training; and interagency coordination of services. Furthermore, health care providers must be aware of the types of patterns used by clients to retain their hope and health (Hall, 1990).

\section{CONCEPTUAL MODEL FOR THE INTERVENTION}

Airhihenbuwa (1990) indicated that the health knowledge within the African American population must include cultural sensitivity and cultural appropriateness to enhance health services. This model is composed of three dimensions of health beliefs and behaviors that are interrelated and interdependent: health education, cultural appropriateness of health behavior, and educational diagnosis of health behavior. The goals of health education are to 
empower the individual to make informed health decisions and to promote good health practices and prevent disease within the community.

Health behavior is heavily influenced by one's health beliefs. The HBM focuses on one's perceptions of his or her susceptibility to a disease as predictors of one's health actions. The key to behavioral intervention with a client is to identify which behaviors (health and non-health related) are most important and changeable (Green, Kreuter, Deeds, \& Partridge, 1980).

\section{HEALTH BELIEF MODEL AND THEORY OF REASONED ACTION}

Three theories have influenced health behavioral prevention research most strongly: the HBM, the Theory of Reasoned Action (TRA), and the Social Cognitive Theory (SCT) (Fishbein et al., in press). A recent consensus panel representing these basic theories identified eight variables posited as primary in predicting and understanding a given behavior regardless of which theoretical model is employed in designing an intervention (Fishbein et al., in press). Of the eight variables, three are viewed as necessary and sufficient conditions for behavioral change: (a) the strong intention $(I)$ to change the behavior, (b) the skill $(S)$ required for behavioral performance, and (c) an absence of environmental constraints $(E C)$.

These three variables $(I, S$, and $E C)$ are important determinants of changing the targeted behaviors (Fishbein et al., in press). The six remaining variables are viewed as influencing the strength and direction of the intention: (a) attitudes, (b) outcome expectancies, (c) perceived norms, (d) self-standards, (e) emotional reactions, and (f) self-efficacy. The conceptual framework for this proposed behavioral evaluation incorporates elements of the HBM, SCT, and the TRA (Fishbein et al., in press).

The HBM has the benefit of specifying a distinct set of cognitions that mediate between modifiable variables (e.g., preventative behavior) and nonmodifiable variables (e.g., demographics, marital status, educational attainment, employment status, income level). The HBM provides a basis for health education, whereas the TRA suggests that one's intention (preceded by attitudes and perceived norms) predicts behavior (Fishbein et al., in press). Evidence also suggests that intentions are stronger predictors of health compliance than are cognitive instructional techniques (DiClemente, 1992). Attitudes toward health outcomes and health practices are shown to be predictive of the client's intentions to use them (Boyd \& Wandersman, 1991). In addition, evidence suggests that the TRA can be enhanced by including perceived self-efficacy, which has been demonstrated to be a strong predictor of 
intention formation and behavior (Bandura, 1992). Self-efficacy appears to affect behavior through a variety of cognitive, affective, and physiological mechanisms (e.g., setting higher standards, lowering stress arousal). Selfefficacy also has been shown to predict and promote adaptive coping and learning skills (Richard \& Van der Plight, 1991). Intentions influencing action may be strongly affected by contextual factors including age, gender, developmental issues, and cultural beliefs (Weisman, Plichta, Nathanson, Ensminger, \& Robertson, 1991). Airhihenbuwa (1990) suggested that African Americans operate in a society where rules and social systems appear to be adversarial. Figure 3 illustrates the interactions among stress, protective factors, and health beliefs. The HBM invites clients to be proactive in managing their health and social problems.

\section{CASE REVIEW METHODOLOGY}

The purpose of this qualitative study was to explore the systemic barriers to the bio-psychosocial and psychoeducational care of two children with sickle cell anemia. One child benefited from a coordinated system of care, whereas the other child did not. The coordinated system of care applied the

principles of comprehensive interventions described by Airhihenbuwa (1990) and the HBM (Fishbein et al., in press).

Using Babbie's (1995) field research methodology, the researchers were able to assess the linkage between the clients' presenting problems and the systems of care that were established to address those problems. Descriptive research involving question-and-answer or archival case study methods allows the researcher to analyze the human and systemic effects for sociological interpretation. Achival and naturalistic studies have proven helpful in designing public health care and public policy programs for treatment and intervention (Babbie, 1995).

\section{CASE HISTORIES}

\section{Case 1}

The child in Case 1 is an 8-year-old African American girl with sickle cell anemia. At the time of the research, she was in the second grade at a suburban elementary school. The client was referred for evaluation because of unexplained disciplinary problems. Specifically, the client was argumentative 


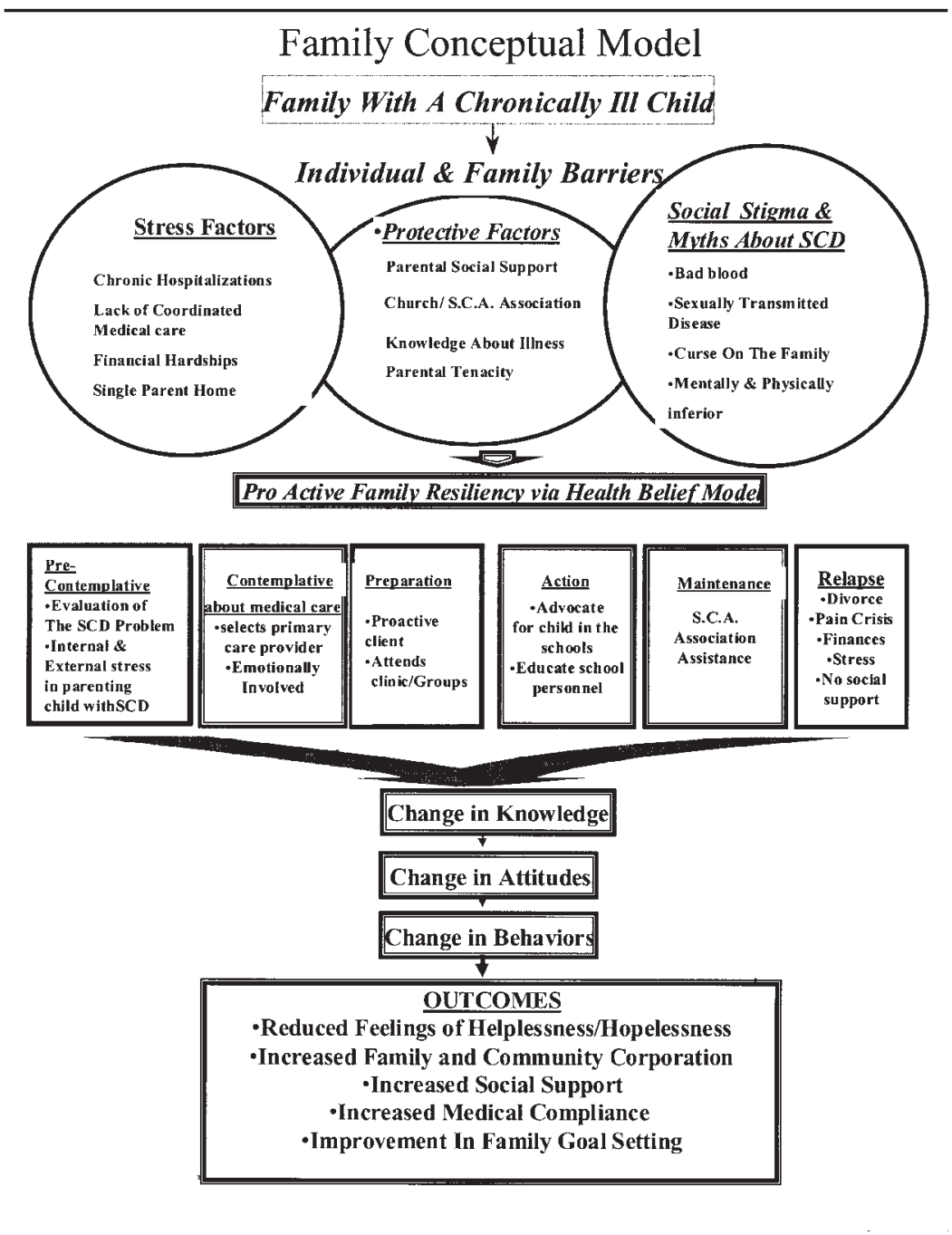

Figure 3: Overview of Health Belief System

NOTE: SCA = sickle cell anemia.

when asked to wait in line, was disoriented in finding her way around the school, and exhibited problems with visual-motor tasks while coloring, cutting, and drawing.

In reviewing the medical history, it was discovered that the student had experienced one stroke at 3 years of age and another at 7 years of age. The 
strokes caused delayed motor skills with specific left-handed weakness, sustained attention concentration problems, and expressive language problems. In addition, she exhibited academic problems with reading, word finding, and word recognition. Neuropsychological testing suggested that the child experienced diffused neurological damage to the parietal lobe areas. Testing also indicated that residual and greater cognitive deficits were experienced in the right parietal hemisphere. These cognitive deficits would seem to coincide with the client's gross motor, fine motor, spatial disorientation, and sequential problem-solving abilities. What initially was perceived as a behavioral problem now was a cognitive/neurological rehabilitation problem.

The mother told school administrators that her child had been diagnosed with sickle cell anemia at birth. School health and administrative officials admitted that they were not familiar with sickle cell anemia and did not know how to provide services for a child with this type of chronic illness. The mother constantly was at odds with school officials because no educational plan had been developed for the child. Eventually, the mother and school officials agreed to admit the child into a homebound program. Unfortunately, appropriate academic goals still were not decided on by that time. The teachers were afraid to come to the student's dangerous and impoverished neighborhood to provide services, and the academic services were terminated by the school without informing the mother of its intent to terminate the services. The mother, after having expressed anger over having the school "abandon" her child, pursued legal action against the district. Over time, the mother became so distressed that she required medication for depression. The mother sent her child to live in another state with her grandmother, and contact was lost with this case.

\section{Case 2}

The mother of a 7-year-old African American boy indicated that her marriage began to suffer 6 months after the child's birth. Her son was diagnosed with sickle cell anemia at 6 months of age. Frequent hospital visits and uncertainty about the child's future also added to the marital tension. The mother had inherited the sickle trait from her parents but was unaware of whether her husband also had the trait. In addition, she believed that sickle cell anemia was "a curse on her family" and often expressed guilt, anger, and frustration as a result. She first became concerned about her son's health when he was 6 months old. Because of his constant crying, she decided to speak with her family doctor. She informed the doctor of her family's history of sickle cell 
anemia. The doctor suggested that she take her son to a hematologist, where he was tested and diagnosed with sickle cell anemia.

By 3 years of age, the child had been in and out of hospitals. As he grew older, he was given medication for pain relief. At approximately $3 \frac{1}{2}$ years of age, the child had a stroke that caused developmental delays. The mother was told that his physical, cognitive, social, and emotional skills would develop at a much slower rate compared to others in his age group.

When the child was 6 years old, he suffered a second stroke that caused paralysis on the left side of his body. Because the medical bills were simply too expensive, the mother applied for but was refused Social Security Disability Income for the child. She eventually filed for bankruptcy and moved in with some of her extended family members. The child became withdrawn and refused to communicate with his former classmates when they came to visit. He also became physically and verbally abusive to his mother and cousins. He was given antidepressants for mood fluctuations. He also received biofeedback sessions for the purpose of pain management. With the antidepressant medication, he became less irritable. Biofeedback sessions were beneficial because they helped to manage the pain he experienced. The hematologist, nurse, and school psychologist met with the child's teachers and school officials to help design a comprehensive program for the child.

As a result of the meeting, his first-grade physical education teacher designed a special program to help the boy with balance and to improve his physical stamina. Because the child also experienced difficulties with his visual-motor and spatial skills, his first-grade teacher requested the assistance of a teacher's aide to work individually with the child in an inclusive classroom setting. As a result of the strokes, the child's cognitive and expressive language skills also were delayed compared to those of his peers.

The mother attended numerous meetings with school officials in regard to the child's medical needs (e.g., need for fluids to prevent dehydration). She also spoke with them in regard to his medication and physical activity levels. However, she and the child continued to make frequent visits to the emergency room. They spent many days in the hospital because of pains in the boy's hands and feet and swelling around his spleen.

The school psychologist encouraged school officials to assign a speech therapist to work with the child on phonetic discrimination and phonetic sounds. The academic review team decided that the child needed more extensive individual attention and advised the school psychologist to contact the chairman of a university in South Texas who specializes in speech and language development. Arrangements were made with the university to work with this child on a tuition-free basis as a teaching case. 
The social worker encouraged the mother to contact the local Sickle Cell Anemia Association, and the mother was given gas vouchers to aid in transporting the child to and from ( 90 miles round-trip three times a week) the university for 1 year. Because of their positive experience with the Sickle Cell Anemia Association, the mother and grandmother began attending a sickle cell anemia support group at church.

When the child was in the sixth grade, he was placed on home-based instruction because of repeated school absences. The school district set up an educational program in which a teacher came to the child's home 4 days a week and worked individually with him on scheduled school assignments. His private tutoring continued through the eighth grade.

\section{DISCUSSION}

The diagnosis of a chronic illness affects not only the individual assessed but also each member of the family and within surrounding systems. There is interconnectedness among the individual; the family; and the medical, psychological, educational, and social (environmental) systems. Because of this interrelatedness among the systems, the incorporation of a multifaceted team approach in providing effective care is needed. In Case 2, the family benefited from a coordinated team effort. The team was composed of the identified client, family, teacher, school psychologist, and hematologist as well as community health professionals, the church, and a nurse case coordinator. This coordinated system of care has been referred to as the bio-psychosocial model of care in which the individual has continuous connections with the systems in which he or she resides and the surrounding systems (Nash, 1994). According to Airhihenbuwa (1990), interaction with family, community, and society requires constant flexibility and adaptation to multiple influences. These include social, economic, cultural, physical environment, human service, and health care influences. Together, these systems work to assist the individual diagnosed with sickle cell anemia and his or her family in adapting and coping in as typical a fashion as possible (Barbarin, 1994).

Although the mother in Case 1 tried to cope with having to care for a child with sickle cell anemia, she did not have the type of coordinated social, financial, spiritual, and educational support systems within the environment to help her cope. She did not live in the vicinity of family members. She was poor and did not know how to get the help that she and her child so desperately needed. In short, she could not cope with the financial and social/emotional stressors that she experienced while trying to care for her child. Social isolation, 
poverty, and racial discrimination also affect how African American families are able to cope under stress (Barbarin, 1994).

The child in Case 1 did not have proper access to education, even though she was registered in the public school system. The school did not fulfill its legal and ethical responsibility to the child and, therefore, to the community and society. When the teacher refused to go into the community and provide an education for the child, the teacher's inaction became the responsibility of the state, thereby having the state refuse the child her property right to an education (Jacob-Timm \& Hartshorne, 1991). This refusal to educate the child violated the individual and civil rights of the child under the 14th Amendment (Jacob-Timm \& Hartshorne, 1991). Additionally, under the same Amendment, the child was not given the right of equal protection and equal educational opportunity, while the parent was not given an opportunity to respond based on the due process under the law (Jacob-Timm \& Hartshorne, 1991). The school system also violated the child's rights under the Individuals With Disabilities Education Act (Public Law 94-142). Under this act, every child with a disability has a right to receive special education and related services in conformance with an individualized education program in the least restrictive environment.

Although both cases had very different outcomes, the global implications of poverty, unlike any other determinant, hovered over each of the families. Because of the scarcity of support from the surrounding systems within the environment (financially and otherwise), the mother in Case 1 saw no other alternative than to send her child away. The inability to pay expensive medical bills and the general need to provide food, clothing, and shelter for her family forced the mother in Case 2 to file for bankruptcy and move in with extended family members. Although filing for bankruptcy was not done for the sole purpose of acquiring the much-needed comprehensive assistance, one is aware that the results from her action would cause some to question her motives. Whatever the answer might be, perhaps one should consider the possibility that a single African American mother living under the cloud of poverty, in many cases, will do whatever is necessary to make sure that her family's needs are met. Would the response of doing whatever is necessary to take care of her family be limited to only poor African American mothers? No, poverty is not biased. The mother in Case 1 demonstrated some of the outcomes of how living in poverty without positive support systems, more than any other environmental factor, will affect thoughts and thereby influence behaviors.

Individuals working with families living in poverty should be aware of the cultural implications so as to improve interventions and strategies to assist 
their clients. In addition, interventionists should have a clear understanding of the cultural dimensions of African Americans in poverty. Culturally aware interventionists will respect the values, rights, beliefs, and worldviews of their clients (Ponterotto, Casas, Suzuki, \& Alexander, 1995). Individuals who have preconceived notions or biases about working with the poor will only serve as barriers to the overall health and coping strategies of those they are attempting to serve.

Individuals with sickle cell anemia are at risk for misunderstanding and misdiagnosis of the illness. Although sickle cell anemia does not get the high-profile attention of other illnesses, it is a critical illness deserving of continued research and public awareness. In addition, the interest in the diseased sickled cells should not outweigh the importance of viewing clients as human beings in need of a coordinated system of care.

\section{IMPLICATIONS AND LIMITATIONS OF THE STUDY}

The limitations of the study include the recognition that it is a qualitative study involving only two case histories. In addition, one of the main limitations of case study research is that the findings cannot be generalized to an entire population. Therefore, it is recommended that an experimental design study be implemented using a larger population and standardized quality of life measures that could quantitatively assess the psychosocial implications of sickle cell disease.

\section{REFERENCES}

Airhihenbuwa, C. (1990). Health promotion and disease prevention strategies for African Americans: A conceptual model. In R. Braithwaite \& S. Taylor (Eds.), Health issues in the Black community (pp. 267-280). San Francisco: Jossey-Bass.

Armstrong, F. D., Thompson, R., Wang, W., Zimmerman, R., Peglow, C., Miller, D., Moser, F., Bello, J., Hurtig, A., \& Vass, K. (1996). Cognitive functioning and brain magnetic resonance imaging in children with sickle cell disease. Pediatrics, 97, 864-869.

Austin, J. K. (1990). Assessment of coping mechanisms used by parents and children with chronic illness. Maternal Child Nursing, 15, 98-102.

Avery, M. E., \& First, C. R. (1989). Pediatric medicine. Baltimore: Williams \& Wilkins. Babbie, E. (1995). The practice of social research (7th ed.). Belmont, CA: Wadsworth.

Bandura, A. (1992). Exercise of personal agency through the self-efficacy mechanism. In R. Schwarzer(Ed.), Self-efficacy: Thought control of action. Washington, DC: Hemisphere.

Barbarin, O. A. (1994). Risk and resilience in adjustment to sickle cell disease: Integrating focus groups, case reviews, and quantitative methods. In K. B. Nash (Ed.), Psychosocial aspects of sickle cell disease: Past, present, and future directions of research. New York: Haworth. 
Barbarin, O., Whitten, C., \& Bonds, S. (1994). Estimating rates of psychosocial problems in urban and poor children with sickle cell anemia. Health \& Social Work, 19(2), 113-119.

Behram, R. E., \& Vaughan, V. C. (1983). Nelson textbook of pediatrics (12th ed.). Philadelphia: W. B. Saunders.

Berg, A. O. (1994). Clinical guidelines and primary care. Journal of American Board of Family Practice, 7(2), 134-139.

Boyd, B., \& Wandersman, A. (1991). Predicting undergraduate condom use with the Fishbein, Ajzen, and Triandis attitude-behavior models: Implications for health interventions. Journal of Applied Social Psychology, 21, 1810-1830.

Brown, R. T., Armstrong, F. D., \& Eckmen, J. R. (1993). Neurocognitive aspects of pediatric sickle cell disease. Journal of Learning Disabilities, 26(1), 33-45.

Brown, R. T., Buchanan, I., Doepke, K., Eckman, J. R., Baldwin, K., Goonan, B., \& Schroenherr, S. (1993). Cognitive and academic functioning in children with sickle cell disease. Journal of Clinical Child Psychology, 22, 207-218.

Brown, R. T., Kaslow, V. J., \& Doepke, K. (1993). Psychosocial and family functioning in children with sickle cell syndrome and their mothers. Journal of American Academy of Child and Adolescent Psychology, 32, 545-553.

Carter, J. H. (1983). Vision or sight: Health concerns for African-American children-The psychosocial development of minority group children. New York: Brunner/Mazel.

Chapar, G. N., Blair, A., \& Stowe, M. (1991). Neuropsychological deficits and sickle cell disease: A continuing investigation. Paper presented at the annual meeting of the National Sickle Cell Disease Program, Mobile, AL.

Charache, S., Lubin, B., \& Reid, C. D. (1989). Management and therapy of sickle cell disease. Washington, DC: Government Printing Office.

Cohen, D., Richardson, J., \& La Bree, L. (1994). Parenting behaviors and the onset of smoking and alcohol use: A longitudinal study. Pediatrics, 94, 368-375.

Department of Health and Human Services. (1992). Management and therapy of sickle cell disease (NIH Publication No. PHS 92-2117). Rockville, MD: National Institute of Health.

DiClemente, R. J. (1992). Psychosocial determinants of condom use among adolescents. In R. J. DiClemente (Ed.), Adolescents and AIDS: A generation in jeopardy. Newbury Park, CA: Sage.

Drotar, D., Baskiewicz, A., Irvin, N., Kennell, J., \& Klaus, M. (1975). The adaptation of parents to the birth of an infant with a congenital malformation: A hypothetical model. Pediatrics, $56,710-717$

Dryfoos, J. (1990). Adolescents at high risk, prevalence, and prevention. New York: Oxford University Press.

Eaton, M. L., Hayes, J., \& Armstrong, F. D. (1991). Relationship between painful episodes, school absenteeism, and academic performance in children with sickle cell anemia. Paper presented at the annual meeting of the National Sickle Cell Disease Program, Mobile, AL.

Farber, M. D., Koshy, M., \& Kinney, T. R. (1985). Cooperative study of sickle cell disease: Demographic and socioeconomic characteristics of patients and families with sickle cell disease. Journal of Chronic Disorders, 38, 495-505.

Fishbein, M., Bandura, A., Triandis, H. C., Kanfer, F. H., Becker, M. H., Middlestadt, S. E., \& Eichler, A. (in press). Factors influencing behavior and behavior change. In A. Baum, T. Revenson, \& J. Singer (Eds.), Handbook of health psychology. Hillsdale, NJ: Lawrence Erlbaum.

Fowler, M. G., Whitt, J. K., \& Lallinger, R. (1988). Neuropsychologic and academic functioning of children with sickle cell anemia. Journal of Clinical Child Psychology, 9, 213-220. 
Francis, R. B., \& Johnson, C. S. (1991). Vascular occlusion in sickle cell disease: Current concepts and unanswered questions. Blood, 7, 1405-1414.

Goldberg, S. (1977). Social competence in infancy: A model of parent-infant interactions. Merrill-Palmer Ouarterly, 23, 163-178.

Green, L. W., Kreuter, M. W., Deeds, S. A., \& Partridge, K. B. (1980). Health education planning: A diagnostic approach. Mountain View, CA: Mayfield.

Hall, B. (1990). The struggle of the diagnosed terminally ill person to maintain hope. Nursing Science Quarterly, 3(4), 177-184.

Hurtig, A. L., Koepke, D., \& Park, K. B. (1989). Relation between severity of chronic illness and adjustment in children and adolescents with sickle cell disease. Journal of Pediatric Psychology, 14(1), 117-132.

Jacob-Timm, S., \& Hartshorne, T. (1991). Ethics and law: For school psychologists (2nd ed.). New York: John Wiley.

Kazak, A. E. (1989). Families of chronically ill children: A systems and social-ecological model of adaptation and challenge. Journal of Consulting and Clinical Psychology, 57, 25-30.

Knafl, K. A., \& Deatrick, J. A. (1986). How families manage chronic conditions: An analysis of the concept of normalization. Research in Nursing and Health, 9, 215-222.

Knafl, K. A., \& Deatrick, J. A. (1990). Family management style: Concept analysis and development. Journal of Pediatric Nursing, 5, 4-14.

Lemanek, K. L., Horwitz, W., \& Ohene-Frempong, K. (1994). A multiperspective investigation of social competence in children with sickle cell disease. Journal of Pediatric Psychology, $19,443-456$

Mills, M. L. (1985). Life-threatening complications of sickle cell disease in children. Journal of the American Medical Association, 254, 1487-1491.

Nash, K. B. (Ed.). (1994). Psychosocial aspects of sickle cell disease: Past, present, and future directions of research. New York: Haworth.

Pizzo, P. A. (1990). Pediatric aids: Problems within problems. Journal of Infectious Diseases, $161,316-325$

Ponterotto, J., Casas, J., Suzuki, L., \& Alexander, C. (1995). Handbook of multicultural counseling. Thousand Oaks, CA: Sage.

Powars, D., Overturf, G., \& Weiss J. (1981). Pneumoccal septicemia in children with sickle cell anemia. Journal of the American Medical Association, 254, 1839-1842.

Rawlins, P. S., Rawlins, T. D., \& Horner, J. (1990). Development of the family needs assessment tool. Western Journal of Nursing Research, 12, 201-214.

Richard, R., \& Van der Plight, J. (1991). Factors affecting condom use among adolescents. Journal of Community Applied Social Psychology, 1, 105-116.

Schlomann, P. (1988). Developmental gaps of children with chronic conditions and their impact on the family. Journal of Pediatric Nursing, 3, 180-187.

Segal, M. (1989). New hope for children with sickle cell disease. FDA Consumer, 23, 14-19.

Sergeant, G. R. (1974). Leg ulceration in sickle cell anemia. Archives of Internal Medicine, 133, 690-694.

Sergeant, G. R. (1992). Sickle cell disease. New York: Oxford University Press.

Sickle Cell Disease Guideline Panel. (1990). Sickle cell disease: Comprehensive screening and management in newborns and infants-Quick reference guide for clinicians (NIH Publication No. 3058). Rockville, MD: National Institute of Health, Public Health Service, Department of Health and Human Services.

Sickle Cell Disease Guideline Panel. (1993). Sickle cell disease: Comprehensive screening and management in newborns and infants-Quick reference guide for clinicians (Vol. 6, AHCPR 
Publication No. 93-0563). Rockville, MD: Agency for Health Care Policy and Research, Public Health Service, Department of Health and Human Services.

Swift, A. V., Cohen, M. J., \& Hynd, G. W. (1989). Neuropsychologic impairment in children with sickle cell anemia. Pediatrics, 84, 1077-1085.

Telfair, J. (1994). Factors in the long-term adjustment of children and adolescents with sickle cell disease: Conceptualization and review of the literature. New York: Hawthorn.

Travis, G. (1976). Chronic illness in children: Its impact on child and family. Stanford, CA: Stanford University Press.

Urwin, C. A. (1988). AIDS in children: A family concern. Family Relations, 37, 154-159.

Walker, D. K., Epstein, S. G., Taylor, A. B., Crocker, A. C., \& Tuttle, G. A. (1989). Perceived needs of families with children who have chronic health conditions. Child Health Care, 18(4), 196-201.

Wang, W. C., Grover, R., \& Gallagher, D. (1993). Developmental screening in young children with sickle cell disease. American Journal of Pediatrics and Oncology, 15, 87-91.

Wasserman, A. L., Wilimas, J. A., Fairclough, D. L., Mulhern, R. K., \& Wang, W. (1991). Subtle neuropsychological deficits in children with sickle cell disease. American Journal of Pediatric Hematology and Oncology, 13(1), 14-20.

Weisman, C. S., Plichta, S., Nathanson, C. A., Ensminger, M., \& Robertson, J. C. (1991). Consistency of condom use for disease prevention among adolescent users of oral contraceptives. Family Planning Perspectives, 23, 71-74.

Whitten, C. F. (1992). Sickle cell anemia and African-Americans: Health issues in the Black community. San Francisco: Jossey-Bass.

Woods, N. F., Yates, B. C., \& Primomo J. (1989). Supporting families during chronic illness. Image Journal of Nursing Scholarship, 21(1), 46-50. 